\title{
APPLICABILITY OF BACTERIAL GROWTH MODELS IN SPREADABLE PROCESSED CHEESE
}

\author{
Dorota Weiss ${ }^{\varpi}$, Anna Kaczmarek, Jerzy Stangierski \\ Department of Food Quality Management, Poznań University of Life Sciences \\ Wojska Polskiego 31, 60-624 Poznań, Poland
}

\begin{abstract}
Background. Food spoilage is a process in which the quality parameters decrease and products are no longer edible. This is a cumulative effect of bacteria growth and their metabolite production, which is a factor limiting shelf life. Thus, the aim of the study was to evaluate whether microbiological growth models for total viable count (TVC) and Clostridium strain bacteria are reliable tools for prediction of microbiological changes in spreadable processed cheese.

Material and methods. Investigations were conducted for two types of bacteria: TVC and Clostridium in following temperature: $8^{\circ} \mathrm{C}, 20^{\circ} \mathrm{C}$ and $30^{\circ} \mathrm{C}$. A total number of aerobic bacteria was determined based on standard PN-EN ISO 4833:2004 and Clostridium was detected by using microbiological procedure for sulphite-reducing anaerobic spore-bacteria with a selective nourishment. During the analysis nonlinear regression and Baranyi and Roberts primary model were used.

Results. For temperatures $20^{\circ} \mathrm{C}$ and $30^{\circ} \mathrm{C}$, Baranyi and Roberts model, for total viable count showed determination coefficient of $70 \%$. The models prepared for Clostridium, in these temperatures, showed much lower $R^{2}$, respectively $25 \%$ and $30 \%$. At the abovementioned temperatures also the expiration of product shelf life was much shorter and amounted 70 days at $20^{\circ} \mathrm{C}$ and 7 days at $30^{\circ} \mathrm{C}$. For both types of bacteria incubated at $8^{\circ} \mathrm{C}$ the numbers of bacteria decrease until the expiration of product shelf life.

Conclusions. Models used in the analyses, Baranyi and Roberts and nonlinear regression, poorly matched the experimental data, hence they are not reliable tools. Nevertheless, they gave information about dynamic of microbiological changes in spreadable processed cheese.
\end{abstract}

Key words: processed cheese, food spoilage, Baranyi and Roberts model, nonlinear regression

\section{INTRODUCTION}

Processed cheese produced with the use of pasteurization is susceptible to spoilage by specific spoilage organisms (SSO). It was indicated that in case of processed cheese SSO include total viable count (TVC) and Clostridium strain bacteria (Roberts and Zottola, 1993; Cichosz, 2000). During pasteurization process Clostridium strains are inactivated however, spore forms remain in the cheese and can be activated under certain conditions and are responsible for deterioration process often connected with gas formation and bad odour (Juneja et al., 1996; Nishihara et al., 2014).

\footnotetext{
*The authors would also like to acknowledge with much appreciation the crucial role of Hochland Polska company, which contributed some research data.

ॠeissd@wp.pl
} 
Ingredients play the crucial role in processed cheese microbial contamination which depends on their microbiological and physico-chemical quality, and quantity used for production. Recent studies show relationship between fat level in dry matter and bacteria survival in processed cheese but also antimicrobial activity of monoacylglycerols used in this products (Buňková et al., 2011; Hauerlandová et al., 2014). Another direction for preventing bacteria growth and product deterioration could be milk fat replacement by inulin which would simultaneously improve texture properties of processed cheese analogues (Sołowiej et al., 2014). Moreover, the inulin was found as an ingredient which can inhibit bacteria metabolites production in dairy products (Karimia at el., 2015).

Ingredients as a source of microbiological contamination can be determined using a discriminatory DNA techniques, like MLST, PFGE or MLVA which helps to identify the strain of bacteria responsible for characteristic product changes (Nishihara et al., 2014).

In order to determine the limit of food safety, microbiologists perform analyses throughout the product shelf life, which the main disadvantages are a timeconsuming and high price.

As an alternative a predictive microbiology based on mathematical modelling can be used, which helps to save time necessary for tests execution and performance (Bruckner et al., 2013). The most important factor of these tests is temperature, especially if products require cold chain during their storage and distribution (Wells and Singh, 1998).

Mathematical models are simplified versions of change processes in food and include only these parameters that are possible to measure. It is believed that models with one or two parameters are more practical than the ones with more factors. Generally, nonlinear regression and sigmoidal curves like Gompertz or logistic function are used for mathematical modelling (Derlieghere et al., 2009). Another widely used primary model is Baranyi and Roberts model, which describes microbiological growth related to their physiological condition (Tarczyńska et al., 2012). Levels of microorganisms growth and their interaction allow for the determination of the dynamics of products spoilage (Cichosz, 2000; Roberts and Zottola, 1993).

Thus, the aim of the study was to evaluate whether bacterial growth models are reliable tools for prediction of microbiological changes in spreadable processed cheese.

\section{MATERIAL AND METHODS}

\section{Processed cheese samples preparation}

Samples of spreadable processed cheese used in the study were obtained from the manufacturer immediately after production. In the process of production the following raw materials were used: natural ripened cheese, milk proteins, butter, emulsifying salts, water and salt. Raw materials were selected, then underwent the process of grinding and weighing. Materials were dosed to batch cooker where melting process took place at pasteurization temperature $80-85^{\circ} \mathrm{C}$ and within 5 min. Pasteurization resulted in a stable cheese mass, which was packed into plastic tubes. In the next stage the packed tubes were cooled in a flowing cooler system within $40 \mathrm{~min}$ and after this period cheese reached $30^{\circ} \mathrm{C}$ (Cichosz, 2000; Kycia, 2005). Immediately after production the samples were incubated at the following temperatures: $8^{\circ} \mathrm{C}, 20^{\circ} \mathrm{C}$ and $30^{\circ} \mathrm{C}$. It presented matching the model to the experimental data depending on the temperature. Samples from three batches were stored in these temperatures until the end of the shelf life or until some visual changes appeared which are characteristic for product spoilage. Spoiled products define samples with significant changes in colour, consistency, smell (off-odours) and with gassing defects.

\section{Microbiological analysis}

Collected 9 samples for each temperature, were homogenized with Ringer liquid in order to prepare a uniform solution. The homogenization, lasting 60 seconds, was performed in a Stomacher machine 400 (Seward Ltd, UK). Three dilutions were prepared as follows: $10^{-1}, 10^{-2}$ and $10^{-3}$. Microbiological determinations were made for: a total number of aerobic mesophilic bacteria (TVC) and Clostridium.

A total number of aerobic bacteria was determined based on standard PN-EN ISO 4833:2004. It is a plate method with nutrient agar and incubation temperature at $30^{\circ} \mathrm{C}\left( \pm 1^{\circ} \mathrm{C}\right)$ for $72 \mathrm{~h}( \pm 3 \mathrm{~h})$. The obtained results were defined as colony forming unit (cfu) per g (PN-EN ISO 4833:2004).

Clostridium was detected by using microbiological procedure for sulphite-reducing anaerobic 
spore-bacteria with a selective nourishment DRCM (Merck, Darmstadt, Germany) containing iron (III) sulphate (IV). The nourishment was prepared in accordance with the manufacturer's guidelines and then $10 \mathrm{ml}$ was added to the tubes. For each dilution: $10^{-1}$, $10^{-2}$ and $10^{-3}$ three parallel tubes were prepared, which were filled with $1 \mathrm{ml}$ of homogenous dilution and then they were plugged with paraffin. The tubes were heated at $83^{\circ} \mathrm{C}\left( \pm 1^{\circ} \mathrm{C}\right)$ for 15 min in a water bath in order to eliminate vegetative cells and cooled afterwards. This procedure involved the incubation of tubes at $37^{\circ} \mathrm{C}\left( \pm 1^{\circ} \mathrm{C}\right)$ for 4 to 5 days. The tubes were considered positive if they showed black deposits and on this basis the most probable number of bacteria was calculated (MPN) (Mead, 1995). The number of bacteria was described as a colony forming unit (cfu) per $1 \mathrm{~g}$ according Most Probable Number Table (Sutton, 2010).

\section{Mathematical analysis}

Microbiological data were transformed using logarithm $\log _{10}$, which is a standard procedure (Nicolaï and Van Impe, 1996) before the mathematical analysis was performed. During the study nonlinear exponential regression was applied for statistical analysis, which described the growth of a total viable count and Clostridium in a specific period of time. Also, Baranyi and Roberts primary model (Fakruddin et al., 2011) was used, which is shown below:

- Baranyi and Roberts equation (1994):

$$
y(t)=y_{0}+\mu_{\max } A(t)-\ln \left(1+\mathrm{e}^{\left.\mu \max A(t)-1 / \mathrm{e}^{(\mathrm{ymax}-\mathrm{y} 0)}\right)}\right.
$$

where: $y(t)$ - cell density at time $t, y_{0}-$ initial cell density, $\mu_{\max }$ - maximum rate of growth, $A(t)$ - a difference between cell density in a specific time $t$ and $t_{0}$, $y_{\max }-$ maximum cell density.

The accuracy of matching with the primary model was evaluated, including the calculation of determination coefficient $\left(R^{2}\right)$ and root mean square error (RMSE).

- Root mean square error (Wang et al., 2010):

$$
R M S E=\sqrt{\frac{\sum_{i=1}^{n}\left(X_{\mathrm{obs}}-X_{\text {model }}\right)^{2}}{n}}
$$

where: $X_{\text {obs }}-$ observed values, $X_{\text {model }}-$ modelled values, $n$ - the number of experimental points.
Statistical analysis was performed with the use of statistical software Statistica 10 (StatSoft, Krakow, Poland) and DMFit version 3.0 (http://modelling.combase.cc/DMFitDB.aspx).

\section{RESULTS AND DISCUSSION}

\section{Nonlinear regression}

Nonlinear regression defining the dependence between the number of TVC bacteria and storage time gave the curve with negative slope at $8^{\circ} \mathrm{C}$. This reduction was observed for 120 days and was constant $(0.85$ $\log _{10} \mathrm{cfu} / \mathrm{g}$; Fig. 1).

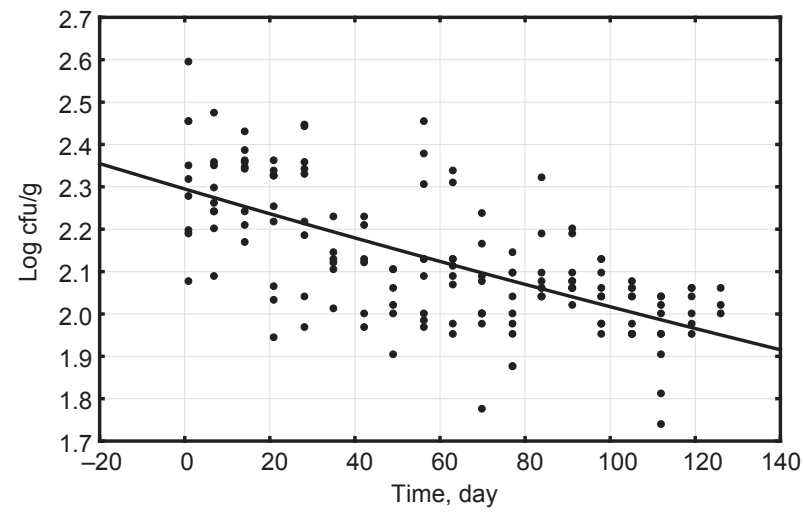

Fig. 1. Total viable count growth $(\log \mathrm{cfu} / \mathrm{g})$ in processed cheese stored at $8^{\circ} \mathrm{C}\left(y=2.29504 \cdot 0.99871^{\wedge} x\right.$; where: $x-$ time, $y$ - count)

In case of Clostridium incubated at $8^{\circ} \mathrm{C}$ it was found that their numbers decreased similarly to TVC during the storage until the expiration of the product shelf life (120 day) the same effect was reported by Muir et al. (1999). The largest decrease in the number was observed between $1^{\text {st }}$ and $20^{\text {th }}$ day, then it slowed down and remained at the same level until the end of incubation time (Fig. 2).

The negative slope during 120 days of storage matches the time declared by the manufacturer as a product shelf life. The reasons for the decreasing number of both types of bacteria are the unfavourable conditions for their development and probably also the presence of polyphosphates as suggested Steeg et al. (1995). Therefore, this could suggest that it might be 


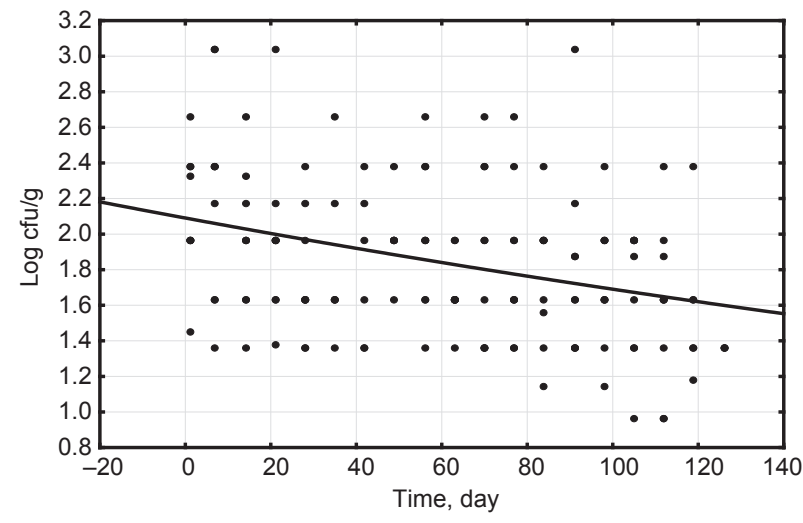

Fig. 2. Clostridium growth (log cfu/g) in processed cheese stored at $8^{\circ} \mathrm{C}\left(y=2.09045 \cdot 0.997877^{\wedge} x\right.$; where: $x$ - time, $y$ - count)

possible to prolong the product shelf life. Nonetheless, some physicochemical changes in products (consistency, smell) could develop during such a long storage time which is indicated by Buňka et al. (2008).

\section{Primary models}

It was noticed that samples incubated at $20^{\circ} \mathrm{C}$ and $30^{\circ} \mathrm{C}$ TVC showed a comparable initial density. Bacteria in both temperatures did not show lag time, which is necessary to prepare microorganisms for the new environment. Cell density grew faster at $30^{\circ} \mathrm{C}$ and the highest value was obtained after 4 days (Fig. 3). Samples were spoiled within 6 to 7 days after production which was manifested by gassing defects and off-odours.

Samples showed differences in dynamics growth between the two previously mentioned temperatures. Those kept at $20^{\circ} \mathrm{C}$ showed a shorter storage period, lasting up to 70 days after production (Fig. 4). The maximal TVC concentration was obtained after 19 days.

The initial levels of Clostridium present in the samples incubated at different temperatures were compared and were $1.79 \log _{10}(\mathrm{cfu} / \mathrm{g})$ and $1.88 \log _{10}(\mathrm{cfu} / \mathrm{g})$ for $20^{\circ} \mathrm{C}$ and $30^{\circ} \mathrm{C}$, respectively (Fig. 5, 6). Lag time was observed at both temperatures and for $20^{\circ} \mathrm{C}$ the adaptation phase lasted almost 7 times longer. The dynamics of population growth was the highest between $5^{\text {th }}$ and $6^{\text {th }}$ day of storage. Similarly to the results obtained in the analysis at $20^{\circ} \mathrm{C}$, the number of Clostridium was lower than total viable count (TVC; Fig. 4).

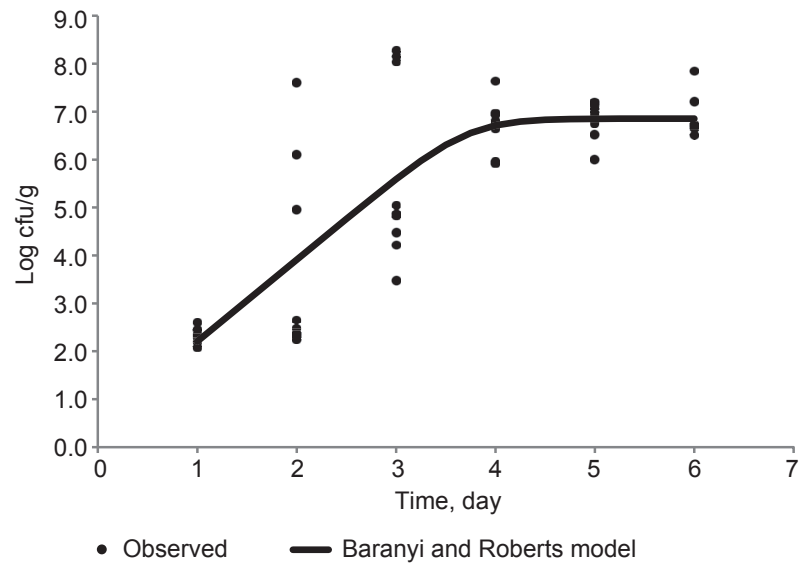

Fig. 3. Baranyi and Roberts model for total viable count (log $\mathrm{cfu} / \mathrm{g}$ ) in processed cheese stored at $30^{\circ} \mathrm{C}$

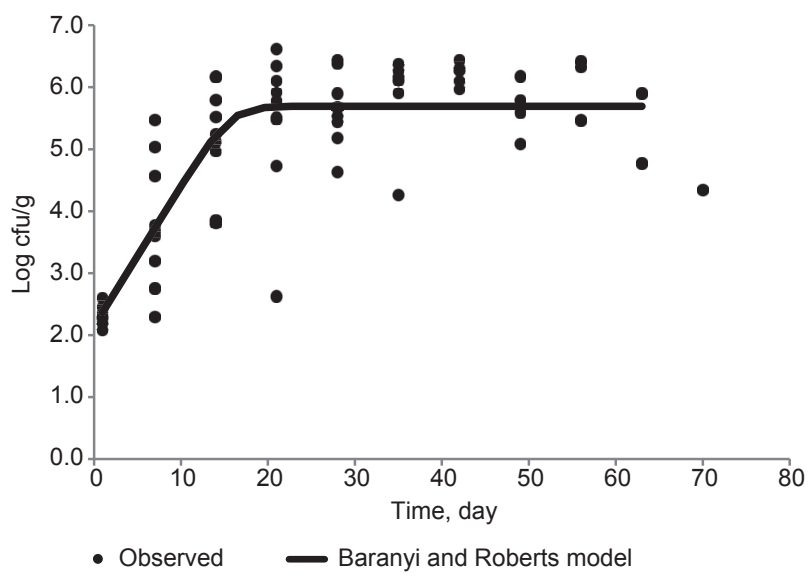

Fig. 4. Baranyi and Roberts model for total viable count (log $\mathrm{cfu} / \mathrm{g}$ ) in processed cheese stored at $20^{\circ} \mathrm{C}$

The models prepared for Clostridium, in both abovementioned temperatures, showed much lower $R^{2}$ but on the other hand, the value of the RMSE appeared to be the lowest (Table 1). It means that the predicted bacteria growth is relatively close to the observed growth but this variability is only partly described by this model. Although, determination coefficient for TVC reached a satisfactory value $(70 \%)$, it allows only for limited application to predict the growth.

The lag time was noticed only for Clostridium incubated at $20^{\circ} \mathrm{C}$ and $30^{\circ} \mathrm{C}$ (Table 2). At higher 


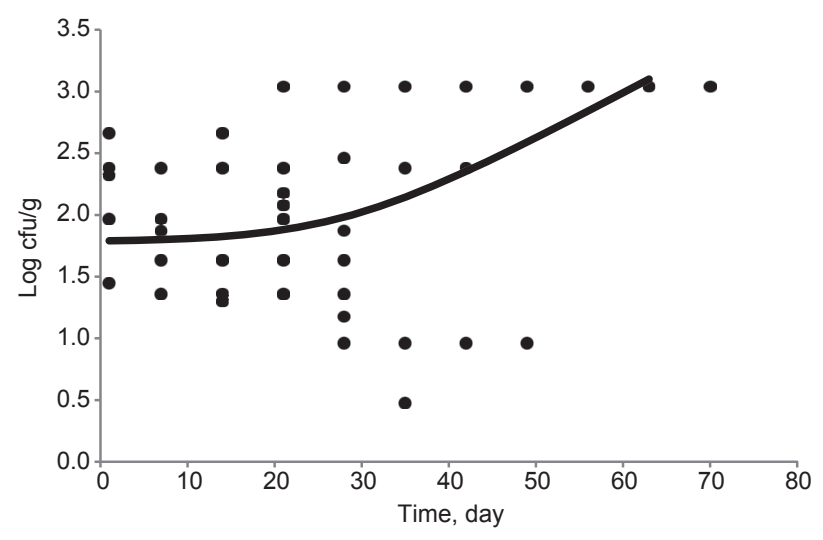

- Observed $\quad$ Baranyi and Roberts model

Fig. 5. Baranyi and Roberts model for Clostridium (log $\mathrm{cfu} / \mathrm{g}$ ) in processed cheese stored at $20^{\circ} \mathrm{C}$

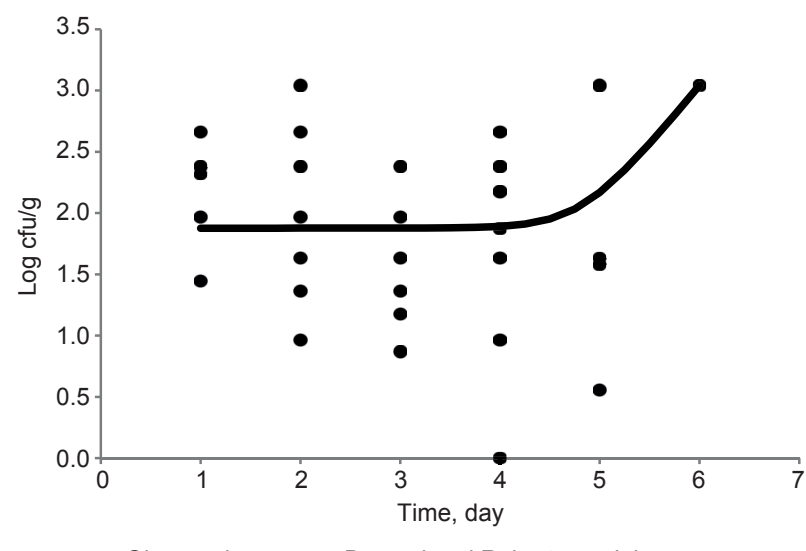

Fig. 6. Baranyi and Roberts model for Clostridium (log $\mathrm{cfu} / \mathrm{g}$ ) in processed cheese stored at $30^{\circ} \mathrm{C}$

temperature the adaptation phase was shorter which means that bacteria need less time for necessary metabolic changes, which prepare cells for divisions. The lack of the observed lag phase for TVC can be the evidence of a very good adaptation of total viable count to the processed cheese environment. On the other hand, it is highly possible that this phase was very short and was not noted in the research.

The Baranyi and Roberts model which is often used for bacteria growth prediction can be also used to
Table 1. Matching accuracy described by $R^{2}$, standard error and RMSE for Baranyi and Roberts primary model for total viable count and Clostridium in processed cheese at $20^{\circ} \mathrm{C}$ and $30^{\circ} \mathrm{C}$ temperatures

\begin{tabular}{cccc}
\hline $\begin{array}{c}\text { Storage } \\
\text { temperature } \\
{ }^{\circ} \mathrm{C}\end{array}$ & $R^{2}$ & $\begin{array}{c}\text { Standard } \\
\text { error }\end{array}$ & $R M S E$ \\
\hline \multicolumn{4}{c}{ TVC } \\
\hline 20 & 0.70 & 0.78 & 0.75 \\
30 & 0.70 & 1.15 & 1.12 \\
\hline \multicolumn{4}{c}{ Clostridium } \\
\hline 30 & 0.25 & 0.64 & 0.63 \\
\hline
\end{tabular}

$R^{2}$ - determination coefficient.

$R M S E$ - root mean square error.

Table 2. Maximum growth rate and lag time for total viable count and Clostridium at different temperatures

\begin{tabular}{ccc}
\hline $\begin{array}{c}\text { Storage } \\
\text { temperature } \\
{ }^{\circ} \mathrm{C}\end{array}$ & $\begin{array}{c}\text { Maximum } \\
\text { growth rate } \\
\log \text { cfu/g }\end{array}$ & $\begin{array}{c}\text { Lag time } \\
\text { day }\end{array}$ \\
\hline & TVC \\
\hline 30 & 0.23 & $\mathrm{n} / \mathrm{a}$ \\
& 1.71 & $\mathrm{n} / \mathrm{a}$ \\
\hline 20 & Clostridium \\
\hline 30 & 0.04 & 27.09 \\
\hline
\end{tabular}

$\mathrm{n} / \mathrm{a}-$ not applicable.

describe the growth of both types of the analysed bacteria at $30^{\circ} \mathrm{C}$ (Derlieghere et al., 2009). However, the primary model poorly matched Clostridium experimental data $\left(R^{2}=30 \%\right)$, whereas for TVC growth at $30^{\circ} \mathrm{C}$ satisfactory determination coefficient $\left(R^{2}=70 \%\right)$ was obtained and mathematical modelling could be applied.

In both temperatures, $20^{\circ} \mathrm{C}$ and $30^{\circ} \mathrm{C}$, the number of bacteria were responsible for visual spoilage effect, which is also described in other studies (Gram et al., 2002) the amount of spoiled bacteria was in the 
level mention by other authors (Suleiman et al., 2011). Spoilage connected with significant changes in colour, consistency, smell and with gassing defects.

\section{CONCLUSION}

This study concluded that nonlinear exponential regression as a bacterial growth model found only limited applicability for prediction microbiological changes in processed cheese. However, this model produced the best results for the data at $8^{\circ} \mathrm{C}$, this temperature was not a factor protecting product against changes in consistency and smell during longer storage period. Baranyi and Roberts model found applicability for the data obtained at $20^{\circ} \mathrm{C}$ and $30^{\circ} \mathrm{C}$, but fitting of $70 \%$ is not satisfactory for prediction growth and it is difficult to call it a reliable predictive tool.

\section{REFERENCES}

Baranyi, J., Roberts, T. A. (1994). A dynamic approach to predicting bacterial growth in food. Int. J. Food Microbiol., 23, 277-294.

Bruckner, S., Albrecht, A., Petersen, B., Kreyenschmidt, J. (2013). A predictive shelf life model as a tool for the improvement of quality management in pork and poultry chains. Food Contr., 29, 451-460.

Buňková, L., Buňka, F., Janiš, R., Krejčí, J., Doležálková, I., Pospíšil, Z., Růžička, J., Tremlová, B. (2011). Comparison of antibacterial effect of seven 1-monoglycerides on food-borne pathogens or spoilage bacteria. Acta Vet. Brno, 80, 29-39.

Buňka, F., Štetina, J., Hrabě, J. (2008). The effect of storage temperature and time on the consistency and color of sterilized cheese. Eur. Food Res. Technol., 228, 223-229.

Cichosz, G. (2000). Wady serów topionych i sposoby ich eliminacji [Defects of processed cheese and ways of their eliminations]. In G. Cichosz (Eds.), Technologia serów topionych (pp. 59-75). Warszawa: Oficyna Wydawnicza „Hoża” [in Polish].

Derlieghere, F., Francois, K., Vermeulen, A., Debevere, J. (2009). Predictive microbiology. In R. Costa, K. Kristbergson (Eds.), Predictive modeling and risk assessment (pp. 29-53). New York: Springer Science+Business Media.

Fakruddin, M. D., Mazumder, R. M., Bin, Mannan, K. S. (2011). Predictive microbiology: Modeling microbial responses in food. Ceylon J. Sci. (Bio. Sci.), 40(2), 121-131.
Gram, L., Ravn, L., Rasch, M., Bruhn, J. B., Christensen, A. B., Givskov, M. (2002). Food spoilage - interaction between food spoilage bacteria. Int. J. Food Microbiol., 78, 79-97.

Hauerlandová, I., Lorencová, E., Buňka, F., Navrátil, J., Janečková, K., Buňková, L. (2014). The influence of fat and monoacylglycerols on growth of spore-forming bacteria in processed cheese. Int. J. Food Microbiol., 37-43, 182-183.

Juneja, U. K., Marmer, B. S., Phillips, J. G., Palumbo, S. A. (1996). Interactive effect of temperature, initial $\mathrm{pH}$, sodium chloride and sodium pyrophosphate on the growth kinetics of Clostridium perfringens. J. Food Protect., 9(59), 963-968.

Karimia, R., Azizi, M. H., Ghasemlou, M., Vaziri, M. (2015). Application of inulin in cheese as prebiotic, fat replacer and texturizer: A review. Carbohydr. Polym., $119,85-100$.

Kycia, K. (2005). Wykorzystanie wszystkich białek mleka do produkcji sera topionego. [Utilizing all milk proteins to manufacture processed cheese] Żywn. Nauka Techn. Jakość, 2(43), 133-146 [in Polish].

Mead, G. C. (1995). Principles involved in the detection and enumeration of clostridia in foods. In J. E. L. Corry, G. D. W. Curtis, R. M. Baird (Eds.), Culture media for food microbiology. Progress in industrial microbiology (Vol. 34, pp. 25-32). Amsterdam: Elsevier Science.

Muir, D. D., Tamime, A. J., Shenana, M. E., Dawood, A. H. (1999). Processed cheese analogues incorporating fatsubstitutes 1 . Composition, microbiological quality and flavour changes during storage at $5^{\circ} \mathrm{C}$. Lebensm.-Wiss. Technol., 32, 41-49.

Nicolaï, B. M., Van Impe, J. F. (1996). Predictive food microbiology: A probabilistic approach. Math Comp. Simulat., 42(2-3), 287-292.

Nishihara, M., Takahashi, H., Sudo, T., Kyoi, D., Kawahara, T., Ikeuchi, Y., ..., Yanahira, S. (2014). Multilocus variable-number of tandem repeat analysis (MLVA) for Clostridium tyrobutyricum strains isolated from cheese production environment. Int. J. Food Microbiol., 190, 61-65.

PN-EN ISO 4833:2004: Horizontal method for the enumeration of microorganisms. Colony - count technique at $30^{\circ} \mathrm{C}$.

Roberts, R. F., Zottola, E. A. (1993). Shelf - life of pasteurized process cheese spreads made from cheddar cheese manufactured with a nisin - producing starter culture. J. Dairy Sci., 76(7), 1829-1836.

Sołowiej, B., Glibowski, P., Muszyński, S., Wydrych, J., Gawron, A., Jeliński, T. (2015). The effect of fat replacement by inulin on the physicochemical properties 
and microstructure of acid casein processed cheese analogues with added whey protein polymers. Food Hydrocolloid., 44, 1-11.

Steeg, P. F., Cuppers, H. G. A. M., Hellemons, J. C., Rijke, G. (1995). Growth of proteolytic Clostridium botulinum in process cheese products. I. Data acquisition for modeling the influence of $\mathrm{pH}$, sodium chloride, emulsifying salts, fat dry basis, and temperature. J. Food Prot., 10, 1059-1064.

Suleiman, T. A. E., Abdalla, M. O. M., Hassan, H., Haj, M. E., Elsiddig, H. M. O. (2011). Chemical and microbiological evaluation of processed cheese available in Khartoum market, Sudan. Am. J. Food Nutr., 1(1), 28-33.

Sutton, S. (2010). The most probable number method and its uses in enumeration, qualification and validation. JVT, $16(3), 35-38$.
Tarczyńska, A. S., Kowalik, J., Łobacz, A. (2012). Modelowanie mikrobiologicznego bezpieczeństwa żywności [Microbiological food safety modelling]. Przem. Spoż., 66, 35-38 [in Polish].

Wang, M., Tang, S. X., Tan, Z. L. (2010). Modeling in vitro gas production kinetics: Derivation of Logistic-Exponential (LE) equations and comparison of models. Anim. Feed Sci. Technol., 165(3), 137-150.

Wells, J. H., Singh, R. P. (1998). Quality management during storage and distribution. In I. A. Taub, R .P. Singh (Eds.), Food storage stability (pp. 369-387). USA: CRC Press LCC.

http://modelling.combase.cc/DMFitDB.aspx.

\section{ZASTOSOWANIE MODELI WZROSTU BAKTERII W SMAROWALNYM SERZE TOPIONYM}

\section{STRESZCZENIE}

Wstęp. Jednym z elementów prowadzących do utraty przydatności do spożycia żywności jest proces zmian mikrobiologicznych. Efektem zepsucia mikrobiologicznego żywności jest niebezpieczne obniżenie jakości lub całkowite wyeliminowanie produktu z obrotu. Wynika to ze wzrostu ilości bakterii oraz produkcji przez nie niebezpiecznych metabolitów. Często zmiany skutkują również ograniczeniem trwałości przechowalniczej produktów spożywczych. Celem badań była ocena czy modele wzrostu ogólnej liczby bakterii oraz Clostridium są niezawodnym narzędziem prognozowania zmian mikrobiologicznych w smarowalnym serze topionym.

Materiał i metody. Badania przeprowadzono w temperaturach $8^{\circ} \mathrm{C}, 20^{\circ} \mathrm{C}$ i $30^{\circ} \mathrm{C}$ dla dwóch rodzajów bakterii: ogólnej liczby bakterii oraz Clostridium. Zastosowano następujące procedury mikrobiologiczne: PN-EN ISO 4833:2004 dla ogólnej liczby drobnoustrojów oraz procedurę oznaczenia najbardziej prawdopodobnej liczby bakterii beztlenowych redukujących siarczyny z wykorzystaniem pożywki selektywnej. W analizach posłużono się regresją nieliniową oraz modelem pierwszorzędowym Baranyiego i Robertsa.

Wyniki. Model Baranyiego i Robertsa uzyskał współczynnik determinacji na poziomie 70\% dla ogólnej liczby bakterii w temperaturach $20^{\circ} \mathrm{C} \mathrm{i} 30^{\circ} \mathrm{C}$. Model przygotowany dla Clostridium w powyższych temperaturach uzyskał znacznie mniejsze wartości $R^{2}$, odpowiednio $25 \%$ i 30\%. Natomiast przydatność do spożycia produktu uległa znacznemu skróceniu, wynosząc 70 dni w $20^{\circ} \mathrm{C}$ i 7 dni w $30^{\circ} \mathrm{C}$. Dla obu grup bakterii inkubowanych $\mathrm{w} 8^{\circ} \mathrm{C}$ liczba bakterii zmniejszała się aż do upłynięcia terminu przydatności produktu.

Wnioski. Zastosowane w analizie modele Baranyiego i Robertsa oraz regresja nieliniowa nie odzwierciedlają w sposób satysfakcjonujący rzeczywistego wzrostu bakterii, nie są więc niezawodnym narzędziem prognozującym. Niemniej jednak pozwalają na określenie dynamiki wzrostu bakterii w serach topionych.

Słowa kluczowe: ser topiony, psucie żywności, model Baranyiego i Robertsa, regresja nieliniowa 